\title{
HONY. SECRETARY GENERAL'S DESK
}

Dear Members,

You are aware that the Bangalore Branch is organizing the National Welding Seminar (NWS 2013), the most prestigious annual event of our institute, to be held at the auditorlum of the Karnataka Trade Promotion Organization (KTPO), Bangalore, Karnataka from 7th-9th February, 2013. Concurrently, the 7th International Welding Technology Exhibition (WELD-INDIA 2013) will also be held at the same venue. I would request all members of our Institute to extend their fullest co-operation for successful conduct of this National event.

Members would be pleased to know that we have just concluded a "MOU" with the American Welding Society (AWS) for organizing our Weld India Exhibitions in association with FABTECH, beginning with the "Weld India 2014" to be held in Pragati Maidan, New Delhi concurrent to the "IC 2014" - the International Welding Congress of the International Institute of Welding. Thereafter such exhibitions will be held once in three years. This arrangement with AWS will undoubtedly open up a new technological window to India, by bringing together manufacturers and users of welding and allied products on the same platform, backed up by the proven expertise of AWS and Fabtech - globally acknowledged names in organizing welding and engineering fares.

IIW-India has also taken a number of steps to take forward its skill development programme and an eleven member working group (WGSDP) has been formed for this purpose. The committee will take all necessary decisions on policy matters in this activity, which would require lot of co-ordination with the National Skill Development Corporation, several sector skill councils, ILF \& S Skill, CII and the also the Skill Development Program of the Govt. of India. Thus, in days to come, our institute is poised to play a major role as the knowledge partner in welding across all verticals. We have therefore decided to promote our NWTCS (National Welding Training and Certification Scheme) by bringing more and more ATI's (Authorized Training Institutes) under its umbrella in addition to supporting the existing ATI's., so that a uniform training program may be conducted throughout the country. I would request all branches to take active initiative with respect to the welding training institutes in their respective geographical areas.

We would soon become a member of CII, who recently involved us in the process of selection of welders for "World Skill Competition" and venue for the same was at "Don Bosco Maritime Academy Mumbai" which is also one of our ATIs . Mr. G. A. Soman - Vice Chairman, IIW Mumbai Branch and Mr. N. K. Sarkar members of the WG-SDP were the observers for this Competition. For all future World Skill Competition also, we would be doing this exercise in association with CII.

While our ANB team has been conducting the International Welding Personnel- Diploma program under Transition Route, as per the revised rules, our ANBCC team has started customer contact programme at different places for ISO 3834 certification of fabrication companies as per IIW's Manufacturers Certification Scheme. One such programme was held at Baroda. Branches are also requested to organize such programmes at the earliest.

Wishing you a Merry Christmas and a very Happy New Year 2013.

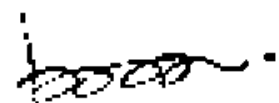

Parimal Biswas

Mobile : +919831052652

E-Mail Id : parimal.biswas@iwindia.com 